\title{
INFLUENCE OF ANTIOXIDANT EFFECT OF STOBADINE DERIVATIVE IN CONDITION OF KIDNEY ISCHEMIA-REPERFUSION IN A PRE-CLINICAL EXPERIMENT (EFFECT IN PROPHYLAXIS)
}

\author{
Jiří Nečass, Lenka Bartošíkováa , Luděk Benešb, Eva Janoštíkováa, Tomáš Bartošík ${ }^{\mathrm{c}}$, \\ Jarmila Klusákovád, Tomáš Florian, Marek Frydrych, Jan Juřica $^{\mathrm{e}}$
}

\author{
a Department of Human Pharmacology and Toxicology, Faculty of Pharmacy, University of Veterinary and Pharmaceutical \\ Sciences, Brno \\ ${ }^{b}$ Department of Chemical Drugs, University of Veterinary and Pharmaceutical Sciences, Brno \\ c Traumatological Hospital, Brno \\ d Pathological - anatomic Institution, Faculty Hospital U sv. Anny, Brno \\ e Department of Biochemistry, Faculty of Medicine, Masaryk University, Brno \\ e-mail:necasj@vfu.cz
}

Received: June 10, 2005; Accepted: September 25, 2005

Key words: Stobadine derivative/Ischemia-reperfusion/Antioxidative enzymes/Laboratory Rat

The goal of the study was to monitor the antioxidative effect of stobadine derivative in the conditions of ischemiareperfusion of laboratory rat kidney tissue. The animals were divided by random selection into 5 groups $(n=10)$. The treated groups were given stobadine derivate in peroral doses of 5,10 and $20 \mathrm{mg} / \mathrm{kg}$ in $0.5 \%$ solution of Avicel once a day; the placebo group was given only the solution of Avicel. The last group was an intact group (without ischemiareperfusion and without treatment). After conclusion of medication on the $15^{\text {th }}$ day all animals were subjected to kidney tissue ischemia (60 min.) followed by reperfusion (10 min.). All animals were subsequently exsanquined and single identification of superoxiddismutase, glutathion peroxidase, total antioxidative capacity, and malondialdehyde level in the blood were determined. Kidneys were recovered for histopathological examination. A statistically significant decrease of the superoxiddismutase and statistically significant increase of the glutathione peroxidase catalytic activity in the treated groups compared to the groups of placebo and intact was discovered. There was also a statistically highly significant increase of total antioxidative capacity in the treated groups compared to the groups of placebo and intact. A statistically significant decrease of malondialdehyde level was identified in the treated groups compared to the groups of placebo and intact. The results of biochemical examination show a protective antioxidative effect of stobadine derivative. The results of histopathological examination support this assumption.

\section{INTRODUCTION}

Stobadine, (-)-cis-2,8-dimethyl-2,3,4,4a,5,9b-hexahydro1H-pyrido[4,3b]indole was developed in the Institute of Experimental Pharmacology of the Slovak Academy of Sciences (Bratislava) and synthetized in co-operation with the Institute of Organic Chemistry and Biochemistry of the former Czechoslovak Academy of Sciences. It is a pyridoindole derivative with a cardioprotective, anti-hypoxic and anti-arrythmical effect.

Acylderivative of stobadine - (heptanoyl) stobadine was prepared by the reaction of stobadine base with heptanoylchloride. The applied substance was in an oxalate form. In the preceding in vitro studies the stobadine acylderivate proved a remarkable antioxidant activity.

The objective of the study was to analyse the dependence of the antioxidative effect of the applied dose of stobadine derivative during prophylactic administration in the conditions of ischemia-reperfusion of kidney in the laboratory rat.
The study and its experimental protocol were approved and monitored by the Ethics Committee of the University of Veterinary and Pharmaceutical Sciences in Brno. The state of health of all animals was inspected regularly several times a day both during the acclimation of the animals and in the course of the whole experiment performed by the work group whose members are holders of the Eligibility Certificate issued by the Central Commission for Animal Protection pursuant to Section 17 of the Czech National Council Act No 246/1992 Coll. on animal protection against maltreatment.

\section{MATERIAL AND METHODS}

The experiments were performed in male Wistar SPF (AnLab, SRN) laboratory rats of the same age and comparable body mass $(250 \pm 10 \mathrm{~g})$. The animals were housed in a room with a standard controlled temperature, fed a standard M1 diet for small laboratory animals, 
and watered ad libitum. After 10 days of acclimation, the animals were randomly divided into 5 groups. The tested compound was administered to three groups of treated animals $(\mathrm{n}=10)$ at concentrations of $5 \mathrm{mg} / \mathrm{kg}, 10 \mathrm{mg} / \mathrm{kg}$, and $20 \mathrm{mg} / \mathrm{kg}$ in $0.5 \%$ Avicel solution perorally once a day. The fourth group $(n=10)$ - the placebo group - was given only $0.5 \%$ Avicel solution in the quantity and by the mode of administration used in the treated groups. The fifth group of animals, the intact one $(n=10)$, was without any medication. After the discontinuation of medication on day 15, laparotomy in general anaesthesia (2\% Rometar $0.5 \mathrm{ml}+1 \%$ Narkamon $10 \mathrm{ml}$, dose $0.5 \mathrm{ml}$ solution/ $100 \mathrm{~g}$ of the rat body mass) was performed, renal ischemia was induced by clamping the left renal artery with a vascular clamp for $60 \mathrm{~min}$ with subsequent $10 \mathrm{~min}$ renal reperfusion. After the termination of reperfusion, the animals were exsanguinated by blood collection from the left ventricle and selected laboratory parameters were analysed - superoxide dismutase (SOD), glutathion peroxidase (GSHPx), total antioxidative capacity (AOC) using RANDOX testing kits (Dublin, Ireland), in COBAS MIRA S automatic analyser, and malondialdehyde (MDA) was analysed spectrophotometrically using the TBARs method ${ }^{1}$. The samples of the reperfused kidney tissue were employed for histopathological examination. After the fixation in neutral $10 \%$ formaldehyde, they were stained with hematoxylin-eosin and examined under an optical microscope. Evaluation principle: all samples in the material were evaluated and scored separately in 3 kidney topicalities, the result was added up and in the end the average score of each medicated group was stated. Scoring schedule: $1^{\text {st }}$ topicality - kidney medulla - the grade of tissue destruction through bleeding (according to the extent) and presence of inflammatory infiltrate ( $\max .+++)$ were evaluated. $2^{\text {nd }}$ topicality - cortex and glomerules - both ex- traglomerular $(+)$ presence of hemorrhages and increased cellularity and extravasates in the glomerule (max. ++ ) were evaluated. $3^{\text {rd }}$ topicality - kidney channels - presence of regressive changes of epithelia from edema to necrosis was evaluated ( + in the case of necrosis and +- in the case of regression not reaching the grade of necrosis). In addition, the channel content was evaluated (protein and hyaline cylinders + ). The highest possible (worst) result per one sample was 7 ( 7 times + ).

The obtained values of the studied laboratory parameters were processed by the Microsoft Excel table processor and statistically interpreted using a non-pair T-test. The value $\mathrm{p} \leq 0.05$ was considered significant.

\section{RESULTS}

The results of laboratory analysis are given in Table 1 . A statistically highly significant decrease of SOD values ( $\mathrm{p} \leq 0.05, \mathrm{p} \leq 0.01$ ) was detected in the groups treated with stobadine derivative at the doses of 5 , and $10 \mathrm{mg} /$ $\mathrm{kg}$, compared with the placebo group. Further, a statistically highly significant decrease of SOD values $(p \leq 0.05$, $\mathrm{p} \leq 0.01$ ) was found in the groups treated with stobadine derivative at the doses of 10 and $20 \mathrm{mg} / \mathrm{kg}$, compared with the intact animal group. Mutual comparison of the SOD values received from the animal groups treated with stobadine derivative at the doses of 10 and $20 \mathrm{mg} / \mathrm{kg}$ showed a significant difference $(\mathrm{p} \leq 0.05)$.

A statistically significant increase in GSHPX values ( $\mathrm{p} \leq 0.05, \mathrm{p} \leq 0.01$ ) was detected in the groups treated with stobadine derivative at the doses of 5 and $10 \mathrm{mg} / \mathrm{kg}$, compared with the placebo group. Further, a statistically significant difference in GSHPx values ( $\mathrm{p} \leq 0.01$ ) was found in the group treated with stobadine derivative at

Table 1. Values of studied laboratory parameters expressed as means \pm SD

\begin{tabular}{|l|c|c|c|c|}
\hline \multicolumn{1}{|c|}{$\begin{array}{c}\text { Group of animals } \\
(\mathrm{n}=10)\end{array}$} & \multicolumn{1}{c|}{$\begin{array}{c}\text { SOD } \\
(\mathrm{U} / \mathrm{ml})\end{array}$} & $\begin{array}{c}\text { GSHPx } \\
(\mu \mathrm{kat} / \mathrm{l})\end{array}$ & $\begin{array}{c}\text { AOC } \\
(\mathrm{mmol} / \mathrm{l})\end{array}$ & $\begin{array}{c}\text { MDA } \\
(\mathrm{mmol} / \mathrm{l})\end{array}$ \\
\hline $\begin{array}{l}\text { Treated } \\
(5 \mathrm{mg} / \mathrm{kg} \text { of hepta- } \\
\text { noylstobadine })\end{array}$ & $210.50 \pm 35.36 *$ & $1045.87 \pm 84.07 *++$ & $0.75 \pm 0.22 *$ & $4.17 \pm 0.97 * *++$ \\
\hline $\begin{array}{l}\text { Treated } \\
(10 \mathrm{mg} / \mathrm{kg} \text { of hepta- } \\
\text { noylstobadine })\end{array}$ & $212.67 \pm 16.79 * *+$ & $1035.63 \pm 36.67 *++$ & $\begin{array}{c}0.62 \pm 0.04 \\
* *+\end{array}$ & $4.19 \pm 0.84 * *++$ \\
\hline $\begin{array}{l}\text { Treated }(20 \mathrm{mg} / \mathrm{kg} \\
\text { of heptanoylstobadine })\end{array}$ & $245.77 \pm 29.56++$ & $989.49 \pm 60.68++$ & $0.71 \pm 0.12 * *$ & $4.07 \pm 0.93 * *++$ \\
\hline Placebo group & $253.54 \pm 20.33 \cdots$ & $962.43 \pm 36.15 \cdots$ & $0.45 \pm 0.07 \cdots$ & $14.06 \pm 1.07 \cdot \cdots$ \\
\hline Intact group & $182.94 \pm 19.81$ & $829.10 \pm 75.69$ & $0.68 \pm 0.04$ & $2.58 \pm 0.33$ \\
\hline
\end{tabular}

$* \mathrm{p} \leq 0.05$ treated vs placebo group, ${ }^{* *} \mathrm{p} \leq 0.01$ tretaed vs placebo group, $+\mathrm{p} \leq 0.05$ treated vs intact group, $++\mathrm{p} \leq 0.01$ treated vs intact group, $\bullet \mathrm{p} \leq 0.05$ placebo vs intact group, $\cdots \mathrm{p} \leq 0.01$ placebo vs intact group 
the doses of 5,10 and $20 \mathrm{mg} / \mathrm{kg}$ in comparison with the intact animal group. Mutual comparison of the GSHPX values received from the animal groups treated with different doses of stobadine derivative showed no significant difference.

A statistically significant increase of AOC values ( $p \leq 0.05, p \leq 0.01$ ) was detected in the groups treated with stobadine derivative at the doses of 5,10 , and $20 \mathrm{mg} / \mathrm{kg}$, compared with the placebo group. Further, a statistically significant change of AOC values $(p \leq 0.05)$ was found in the groups treated with stobadine derivative at the dose $10 \mathrm{mg} / \mathrm{kg}$, compared with the intact animal group. Mutual comparison of the AOC values received from the animal groups treated with different doses of stobadine derivative showed no significant difference.

A statistically highly significant decrease of MDA values $(\mathrm{p} \leq 0.01)$ was detected in the groups treated with stobadine derivative at the doses of 5,10 , and $20 \mathrm{mg} / \mathrm{kg}$, compared with the placebo and intact group. Mutual comparison of the MDA values received from the animal groups treated with different doses of stobadine derivative showed no significant difference.

Comparison of the values obtained from the placebo group and intact animal group showed significant changes of the all biochemical parameters.

Results of histopathological examination are as follows: In the placebo group, massive hemorrhage in the interstitium was observed in all samples, especially on the cortex and medulla boundaries. Hemorrhage also occured in the glomerule area (Bowman's capsule and capillary convolusion) as well as in the medulla. The channels had regressively changed epithelia from the simple edema to epithelia necrosis with all the above described features. In the lumina there was mostly a proteinic content with hyaline cylinder formation. The accompanying edema and the generally increased cellularity of the glomerule were inflammatory reactive. The more marked inflammatory infiltrate was smaller than in the treated groups in the form of sporadic lymphocytes with rare polynuclears. The total average score was oscillating from 5 to 7 . In the intact control group, hemorrhage occurred only accidentally, most probably caused by contusion. In the treated animal groups, the best protective effect was detected at the dose of $5 \mathrm{mg} / \mathrm{kg}$ (score 6,33 ).

\section{DISCUSSION}

The statistically significant changes of SOD and GSHPx levels found in the treated groups confirm the readiness to the destruction of superoxide, disposal of hydrogen peroxide and other free radicals causing injury to the reperfusion sustained kidney tissue. It is supposed that this is a result of the previous preventive supplementation of the animal group with a compound having the in vitro evidenced antioxidative effect. The analysed enzymes act intracellularly and their activity mostly follows one after another. It may be supposed that their activity can change in accordance with the state of organism, or in relation to the on-going pathological processes. The test results demonstrate that the mutual compensation mechanisms formed by the effect coordination of more enzymes can be potentiated by the presence of administered antioxidants.

Individual authors greatly differ in their views on the change of SOD and GSHPx activity caused by the declining function of kidneys. Literature references include both the increasing SOD activity ${ }^{2}$ dependent on the declining function of kidneys and the detection of the reduced SOD

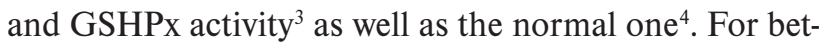
ter assessment of the existing problem it would be more suitable to determine the erythrocyte catalase activity in experimental animals, which is sometimes reduced in patients with declining function of kidneys ${ }^{4}$, and the level of selenium, which has antioxidative effects, forms a part of GSHPX, and the deficit of which is frequently diagnosed in patients with renal failure ${ }^{5}$.

Statistically highly significant increase of AOC values in the treated animal groups was recorded in comparison with the values of the placebo group and also of the intact animal group. It is a significant difference and it may be supposed that this is another logical result of the previous supplementation with a compound with antioxidative effect which was first induced by the lowest dose of stobadine derivative. On the other hand, one of the causes of the AOC increase can also be an increased level of uric acid $^{6}$. The uric acid should be considered to be not only a nitrogenous metabolite of purine compounds but it also has significant antioxidative effects. The authors differ in their views on the AOC changes due to possibly declining function of kidneys ${ }^{7,8}$.

The results of statistical comparison of the MDA values demonstrate significant changes at the statistical significance level $(\mathrm{p} \leq 0.01)$; in the treated animal groups, a statistically significantly lower average value of this toxic by-product of lipid peroxidation was found, compared with the control placebo group. Comparing the results of the performed studies, many authors agree on the increased MDA concentration in plasma or in erythrocytes ${ }^{2}$ in patients with renal failure; however, the cause can be not only its increased formation from lipid peroxides but also its reduced renal elimination ${ }^{6}$. The MDA can subsequently modify the proteins and lead to similar changes which can be observed during their glycation ${ }^{6,9}$.

The positive effect of the antioxidant administration in the conditions connected with ischemia and subsequent reperfusion of kidney tissue in relation to the improvement of the values of the antioxidative system indicators is also discussed in other studies ${ }^{10,11}$.

In our study, the potential protective effect of stobadine derivative is demonstrated in the prophylaxis of ischemic-reperfusion injury to kidney in the laboratory rat. The assumption is supported by the results of the evaluation of histopathological findings in the examined kidney samples. 


\section{ACKNOWLEDGEMENT}

The study was supported by grant No NL/7455-3 of the Internal Grant Agency, Ministry of Health, Czech Republic.

\section{REFERENCES}

1. Uchiyama M, Mihara M. (1978) Determination of malondialdehyd precursor in tissues by thiobarbituric acid test. Anal Biochem 3, 271-8.

2. Mimic-Oka J, Simic T, Ekmescic V, Dragicevic P. (1995) Erythrocyte glutathione peroxidase and superoxide dismutase activities in different stages of chronic renal failure. Clin Nephrol 1, 44-8.

3. Racek, J, Veselá E, Holeček V, Treška V. (1995) The significance of free radicals in patients with renal failure and during kidney transplantation. Klin Biochem Metab 24 Suppl, 4-6.

4. Durak I, Akyol O, Basesme E, Canbolat O, Kavutcu M. (1994) Reduced erythrocyte defense mechanismus against free radical toxicity in patients with chronic renal failure. Nephron 66, 76-80.

5. Bonomini M, Albertazzi A. (1995) Selenium in uremia. Artif Organs 19, 443-8.
6. Racek J, Eiselt J, Holeček V, Veselá E, Krejčová I, Třeška V, Opatrný K, Valenta J. (1997) Free radicals and kidney disease. Klin Biochem Metab 26, 92-7.

7. Jackson P, Loughrey CM, Lightbody JH, McNamee PT, Young IS. (1995) Effect of hemodialysis on total antioxidant capacity and serum antioxidants in patients with chronic renal failure. Clin Chem $41,1135-8$.

8. Toborek M, Wasik T, Drozdz M, Klin M, Magnerwrobel K, Kopiecznagrzebieniak E. (1992) Effect of hemodialysis on lipid peroxidation and antioxidant system in patients with chronic renal failure. Metabolism 41, 1229-32.

9. Roselaar SE, Nazhat NB, Winyard PG, Jones P, Cunningham J, Blake DR. (1995) Detection of oxidants in uremic plasma by electron spin resonance spectroscopy. Kidney Int 48, 199-206.

10. Lee PH, Chung YC, Hu RH, Huang MT, Lee CS. (1992) Protective effect of superoxide dismutase and allopurinol on oxygen free radical-induced damage to the kidney. Transpl Proc 24, 1353-4.

11. Zurovsky Y, Eligal Z, Grossman S. (1995) Unilateral renal ischemia reperfusion in the rat: Effect of blood volume trapped in the kidney, sucrose infusion, and antioxidant treatments. Exp Toxic Path 47, 471-8. 